\title{
Rat Model of Bone Metastasis Obtained by Mammary Cancer Transplantation
}

\section{ORIGINAL ARTICLE Annals of Cancer Research and Therapy}

\section{Akishige Ohta · Takashi Matsubayashi*1), Hitoshi Takahara • Mineko Uemae ${ }^{* 21}$, Shigenobu Nakayama*3)}

\begin{abstract}
Mammary adenocarcinoma was induced by administering 7, 12-dimethylbenz (a) anthracene to inbred female Fischer-344 rats. Then cell suspensions of this mammary cancer were subcutaneously inoculated into other rats of the same strain to obtain transplantable mammary cancer. The transplantable mammary cancer cells were subsequently injected into the femoral medullary cavity of other rats of the same strain to prepare a metastatic bone tumor model.

The cumulative survival rate and the radiographic and histologic changes were determined after inoculation of mammary cancer cells into the femur. In addition, the effect of $\mathrm{X}$-ray irradiation was assessed.

At $5 \sim 7$ days after mammary cancer cells were injected, periosteal spiculation appeared on radiographs. Histological examination showed prominent changes in the resting osteoblast layer lining both the endosteum and the periosteum immediately or 1 day after inoculation. In the vicinity of the tumor cells, a large number of osteoclasts were generated and bone lysis occurred. With the subsequent growth of tumor tissue, bone lysis by osteoclasts and by tumor cells was progressive.

Finally, fracture and/or bone destruction occurred, followed by the death of the animals. Irradiation of the cancer cells at the site of injection into bone prolonged the life-span of the rats.
\end{abstract}

Ann Cancer Res Ther 2 (2) : 193-198, 1993 / Received 15 Jun 1993

Key words : animal model, bone metastasis, mammary cancer, rats, transplantation

Malignant bone tumors arising in humans are generally difficult to cure, have a poor prognosis, and very often cause intolerable pain and disability.

Primary malignant bone tumors, although rare, tend to be more frequent in younger individuals and have a profound effect on the future of such patients. On the other hand, metastatic bone tumors are usually found in comparatively elderly patients, in whom they arise from malignancies such as carcinoma of the lung, breast, and prostate.

The prognosis is often unfavorable for such patients, because metastasis occurs after surgical treatment, radiotherapy, and/or chemotherapy for the primary tumor. Therefore, success with cancer therapy depends on both the curability of the primary lesion and the prevention of metastasis.

The mechanism of cancer metastasis has not yet been fully elucidated either experimentally or clinically. In this study, we prepared experimental bone metastase in rats, and subjected the resulting lesions to histologic and radiologic examination.

\section{Materials and methods}

\section{Animals}

This study used inbred female Fischer-344 rats purchased from Japan Clea Co. (Tokyo). Two animals

"Department of Radiology, " Animal Laboratory, Kitasato University School of Medicine were housed together in stainless steel cages which were kept in an air-conditioned clean room at $25 \pm 1^{\circ} \mathrm{C}$ throughout the experiment. The animals were provided with a pellet diet (CE-2, Japan Clea Co., Tokyo) and tap water ad libitum.

\section{Induction of mammary cancer}

Mammary cancer was induced with an olive oil solution of 7, 12-dimethylbenz (a) anthracene (DMBA) (Eastman Kodak Co., Rochester, USA), which was given orally to the rats twice at the ages of 8 and 9 weeks $(30 \mathrm{mg} / \mathrm{kg}$ each time). The rats given DMBA were examined once a week to detect the development of cancer and tumor masses which grew to $2 \sim 3 \mathrm{~cm}$ in diameter were dissected out for transplantation.

\section{Transplantation}

The DMBA-induced mammary cancers were histologically shown to be adenocarcinomas.

The dissected tumor tissue was cut into thin slices with scissors under sterile conditions, and was made into a cell suspension by simple mechanical compression using rubber. After phosphate-buffered saline (pH7.4) containing 1\% trypsin (Difco co., $250: 1$ ) was added to the tumor suspension for digestion, cancer cells were isolated by centrifugation at $600 \mathrm{G}$. Then the isolated cells were suspended again, and $1 \times 10^{6}$ cells $(1 \mathrm{ml})$ were injected subcutaneously into rats of the same strain at the mammary line of the ventral chest wall. Mammary cancer cells which acquired 


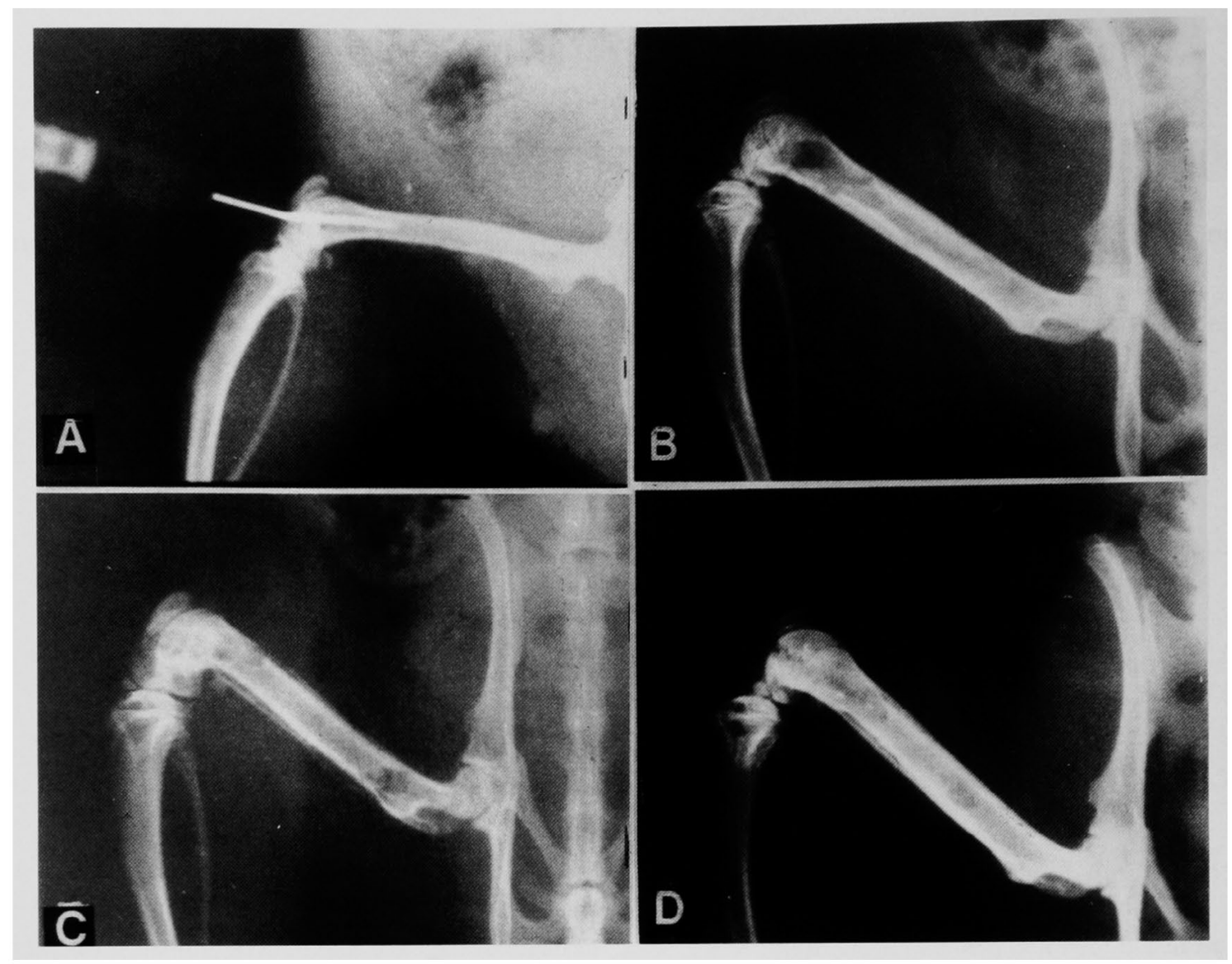

Fig.1 Radiographs showing the injection of mammary cancer cells into the femur of a rat (A), and the femurs region of rats with transplanted cancer at one week after inoculation $(B \sim D)$ An early periosteal reaction is evident in $C$.

transplantability by this procedure were subsequently maintained by injecting them into the subcutaneous tissue of the lateral chest wall of rats of the same strain every 6 weeks.

Transplantation of mammary cancer cells into medullary cavity

Intraosseous transplantation of mammary cancer cells was done by inoculating $1 \times 10^{6}$ cancer cells $/(50 \mu 1$ of cell suspension) into the left femoral medullary cavity of rats by direct injection with $21 \mathrm{G}$ needle through the anterior intercondylar fossa under Nembutal anesthesia (Fig.1A).

\section{Histological examination}

Bone tissue for histological examination was operatively resected with scissors, fixed in $10 \%$ phosphate-buffered formalin solution for 1 week, and then decalcified in $3 \%$ ethylenediaminetetraacetic acid sodium salt solution (EDTA). The tissue was then embedded in paraffin and stained with hematoxylin and eosin.

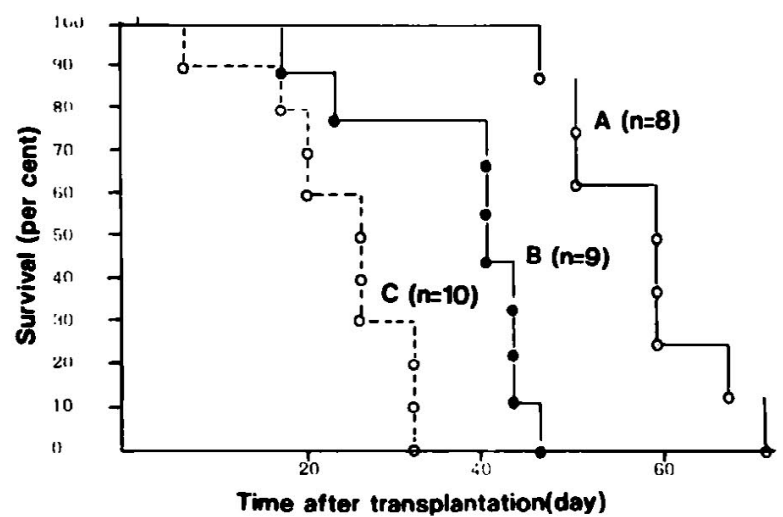

Fig.2 Kaplan-Meier plot of survival after 45 Gy of local bone irradiation (B : - - - -)

Inoculation of $1 \times 10^{6}$ mammary cancer cells on day 0 followed by irradiation on day 7 .

C: intraosseous injection only $(\cdots \bigcirc \cdots \bigcirc \cdots)$,

A: subcutaneous injection only $(-\mathrm{O}-\mathrm{O}-$ ).

(Subcutaneous injection vs. intraosseous injection: $p<0.01$ : Intraosseous injection vs. intraosseous injection plus irradiation : $p<0.05$ )

\section{Radiography and $X$-ray irradiation}

Radiographs were taken using a portable $X$-ray machine (KCD-10M-6AT, Toshiba Co., Tokyo), and X- 


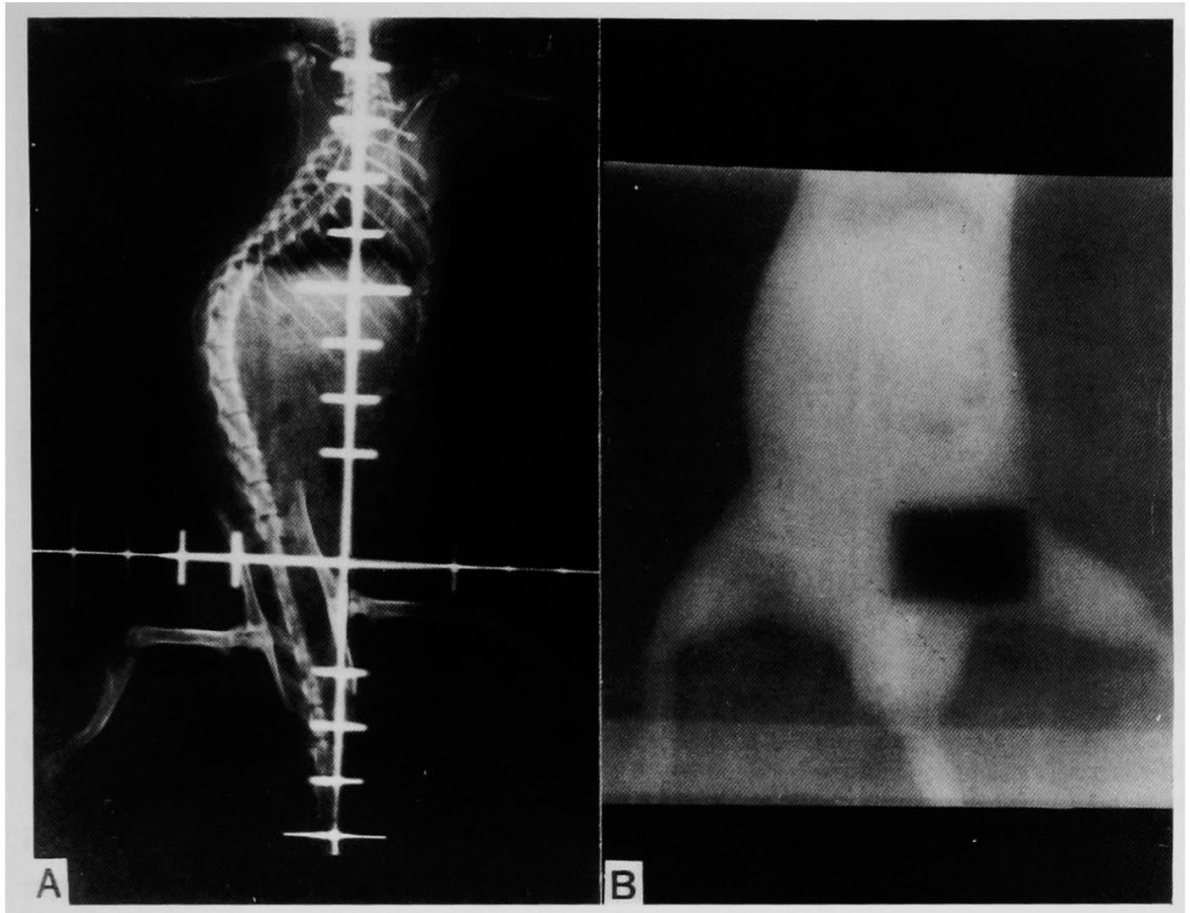

Fig.3

Arrangement of the anterior field for a rat femur with transplantable mammary cancer (A) and verification film obtained for irradiation with the $4 \mathrm{Mev}$ linear accelerator (B).

ray irradiation was performed using a $4 \mathrm{MeV}$ linear accelerator (Linac, NEC, Tokyo).

\section{Statistical analysis}

Calculation of cumulative survival rates was done by the Kaplan-Meier method", while statistical analysis of the significance of differences was done with the generalized Wilcoxon test ${ }^{2}$.

\section{Results}

\section{Induction and transplantation of mammary cancer}

DMBA was given orally to 48 female Fischer rats from the age of 8 weeks, and 45 of them survived for at least 25 weeks. Macroscopic cancer growth was observed in 37rats by 25 weeks after administration. These tumors were categorized as follows : 8 papillary adenocarcinomas, 13 medullary carcinomas, 2 scirrhous carcinomas, 14 fibroadenomas, 5 mixed malignancies comprising papillary adenocarcinoma and medullary carcinoma, and 14 mixed tumors comprising adenocarcinoma and fibroadenoma. There were no tumors in 8 rats. All the papillary adenocarcinomas and medullary carcinomas were subjected to transplantation, and these cancers were all successfully transplanted. In the present study, one of these transplantable mammary tumors was used.

When the transplantable mammary cancer cells obtained as mentioned above were injected into the femoral medullary cavity, they continued to proliferate in all cases, causing osteolysis and periosteal new bone

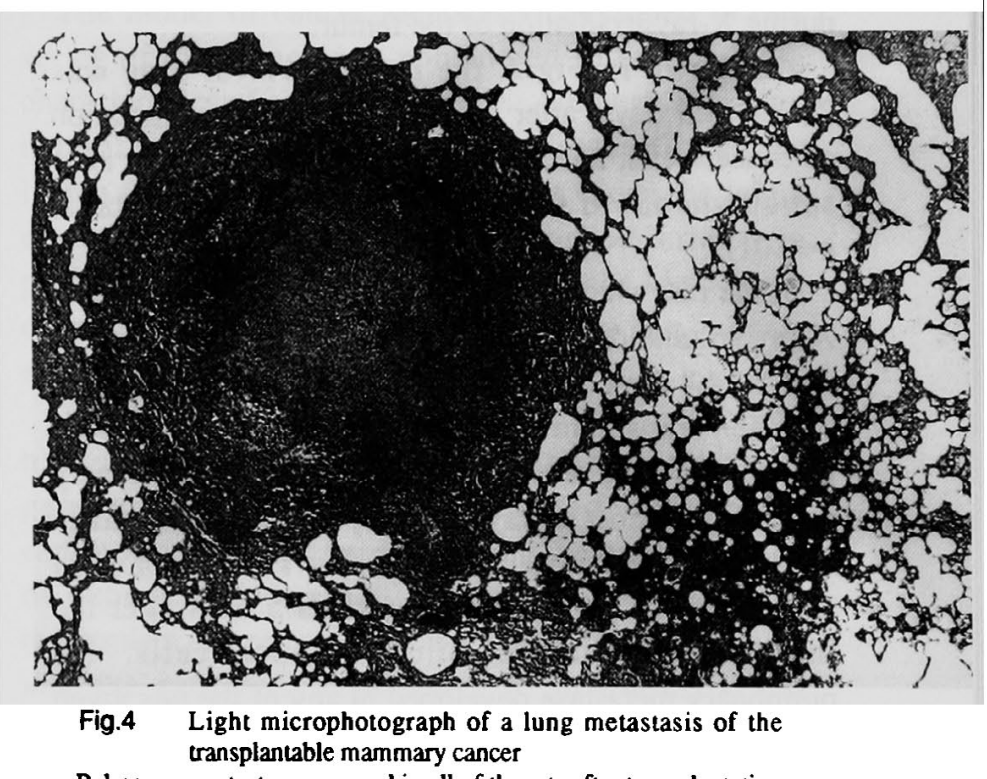

Pulmonary metastase occurred in all of the rats after transplantation (hematoxylin and cosin stain, $\times 320$ ).

formation (Fig.1) that was followed by fracture. Finally, after progressive bone destruction (Fig.5), the rats died while bearing large cancers which had grown very rapidly.

\section{Characteristics of tumor proliferation in bone}

Fig. 2 show the cumulative survival rate data for rats inoculated with $1 \times 10^{6}$ cancer cells into the subcutaneous tissue of the lateral chest wall or into the femur, and for rats which underwent X-ray irradiation (45Gy) of the tumor-injected bone at 1 week after inoculation.

Fig.3 shows a Lineac radiograph taken for verification 


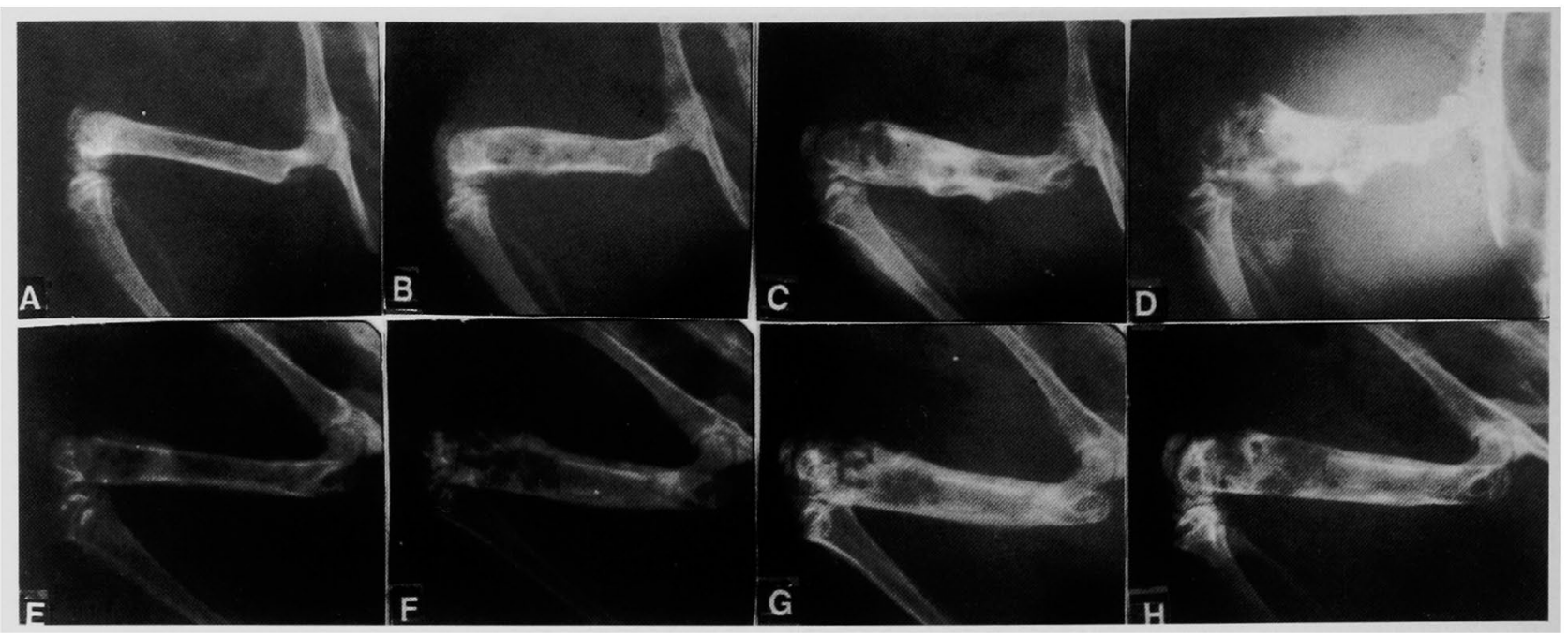

Fig.5 Anteroposterior radiographs of the femurs of rats with transplantable mammary cancer $A \sim D$ : Serial films taken at $1,2,3$, and 4 weeks show the sequence of events after transplantation of the tumor cells. $\mathrm{E} \sim \mathrm{H}$ : Films showing the effect of irradiation on tumor growth in bone.

$E$ : Periosteal reaction is seen at one week after transplantation when the tumor was irradiated.

F : One week after irradiation. $G$ : Two weeks after irradiation. $\mathrm{H}$ : Three weeks after irradiation.

during $\mathrm{X}$-ray irradiation of the femur.

As shown in Fig.2, the mean survival time was $21.1 \pm 11.3$ days, after the intraosseous transplantation of cancer cells, and was significantly shorter than after subcutaneous transplantation $(47.5 \pm 24.7$ days, $\mathrm{p}<0.01$ ).

In the rats which received intraosseous transplantation, $\mathrm{X}$-ray irradiation prolonged the mean survival time to $34,8 \pm 14.4$ days $(\mathrm{p}<0.05)$.

When transplantable mammary cancer cells were injected into the femoral medullary cavity, pulmonary metastase almost always developed at an early stage following inoculation. Figure 4 shows the histological appearance of pulmonary metastases 5 days after the intraosseous transplantation of cancer cells. No pulmonary metastase developed in any of the rats given subcutaneous inoculations of mammary cancer cells.

\section{Radiographic bone changes after cancer cell transplantation}

After the transplantation of cancer cells, radiography demonstrated osteolysis and a moth-eaten appearance indicating bone destruction along with disruption of the cortex and the growth of extraosseous soft tissue masses. (Fig.1B $\sim$ D).

In almost all the rats receiving intraosseous transplantation, periosteal spiculation appeared about one week after inoculation.

Fig.5 (A D ) shows femoral radiographs taken at weekly intervals after the intraosseous inoculation of cancer cells. The radiographs in Fig. $5(\mathrm{E} \sim \mathrm{H})$ show cancer cell-injected bone which received $\mathrm{X}$-ray irradiation at 1 week after inoculation.

When the femur was irradiated ( $45 \mathrm{~Gy}$ ) after intraosseous tumor inoculation, bone destruction ceased or was delayed.

\section{Histological bone changes after cancer cell transplantation}

When cancer cells were injected into the medullary cavity, the surrounding tissues underwent sudden changes. Fig. 6 shows a photomicrograph of the endosteum and periosteum in the metaphyseal region obtained 11 days after inoculation of transplantable mammary cancer cells into the femoral marrow cavity. Bone resorption by osteoclasts can be seen to affect both the endosteum and the periosteum.

\section{Discussion}

There have been numerous studies on bone metastasis ${ }^{3-6)}$, but the mechanism involved has still not been elucidated.

The question of which cells can act as osteoclast progenitor cells is an important theme of current research in this field.

In this study, a rat model of bone metastasis was prepared by inoculating transplantable mammary cancer cells into inbred Fischer rats, and the bone lesion were examined radiographically and microscopically. We demonstrated that transplanted mammary cancer cells caused bone resorption at both the endosteal and periosteal surfaces within a few days after inoculation, and subsequently shortened the life span of the rats as 


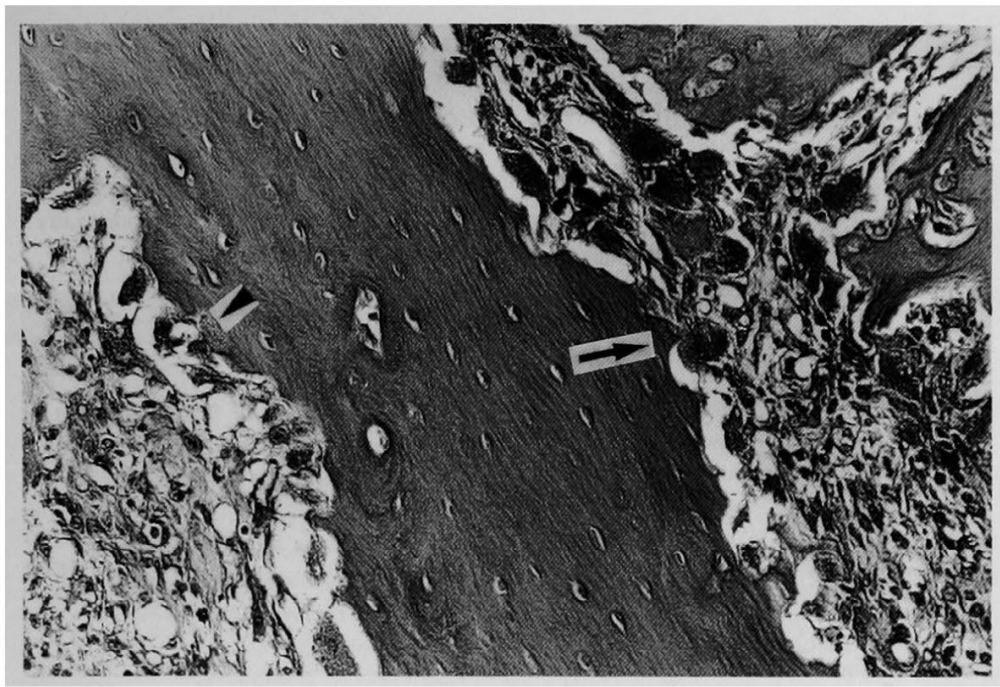

Fig.6 Histological findings of the proximal metaphyseal region of a rat femur inoculated with mammary cancer cells

The multinucleated giant cells are osteoclasts. Eleven days after the inoculation of cancer cells, there is marked osteolysis with cortical destruction affecting both the endosteum (arrowhead) and the periosteum (arrow) (hematoxylin and eosin stain, $\times 160$ ).

bone destruction progressed.

Among the previous studies on experimentally induced bone metastase, those using rabbit $\mathrm{Vx}_{2}$ tumor reported by Galasko" and by Cerino and King et al ${ }^{\text {s) }}$ are well known. $\mathrm{Vx}_{2}$ carcinoma is a transplantable rabbit tumor that is frequently used for experimental purposes. Galasko et al. have performed numerous radiological and histological studies of this tumor". Both Cerino et al. and Galasko et al. inject $\mathrm{Vx}_{2}$ carcinoma cells into the marrow of the rabbit tibia through a hole made with a dental drill. The rat is the most frequently used experimental animal next to the mouse. Dixon et al. have studied lymph node metastasis using transplantable mammary cancer cells and the inbred rats ${ }^{10)}$.

More recently, Yamasaki et al. ${ }^{11)}$ prepared an animal model of bone metastasis using transplantable osteogenic tumors obtained by the administration of radioactive phosphorus to rats. Transplantable osteogenic tumor cells were injected subperiosteally into the tibia.

We prepared transplantable mammary carcinoma cells by the serial transplantation of mammary cancers produced by administration of a chemical carcinogen to inbred rats. These transplantable mammary cancer cells were injected with $21 \mathrm{G}$ needle into the femoral marrow of rats to prepare a model of bone metastasis. After transplantation of the mammary cancer cells, bone resorption by osteoclasts affected both the endosteum and the periosteum, new bone formation by osteoblasts occurred on the surface of the periosteum, and a series of phenomena involving bone remodeling and fracture were observed due to accelerated bone resorption by activated osteoclasts in association with rapid tumor proliferation.

The general course of tumor metastasis is that tumor cells from the primary lesion arrive in an organ through the blood stream or lymph flow, grow until the affected organ is destroyed, and eventually cause the death of the host.

The model of cancer metastasis developed in this series of experiments is considered to reflect these characteristics of cancer behaviour. Although it is not a natural mode of metastasis making use of blood or lymph flow, direct take of tumor cells inside the target organ is possible. Furthermore, this method is simple to perform and uses a tumor derived from the same strain of rats. It is also feasible to manipulate the animals easily because of their medium size.

The issues to be studied in the future include histologic and physiologic clarification of the generation of osteoblasts and osteoclasts in the endosteum and periosteum following the transplantation of cancer cells, as well as determination of the mechanism of bone resorption and new bone formation, and the radiation sensitivity of osteoblasts and osteoclasts. Further studies on these topics are in progress.

Acknowledgement : This work was supported in part by a Grant-in Aid for cancer research (T.M. : 60-4) from the Japanese Ministry of Health and Welfare.

\section{References}

1) Kaplan, E. L., Meier, P : Nonparametric estimation from incomplete observations. Am Stat Assoc J 53 : 457-481, 1958.

2) Gehan $E:$ A generallized Wilcoxon test for comparing arbitrarily singly censored samples. Biometrika, 52 : 203-223, 1965.

3) Lote $\mathrm{K}$, Wallo EA, Bjersand A : Bone metastasis. Acta Radiol Onc, $25: 227-232,1986$.

4) Matsubayashi T, Koga. H et al. : The process of metastatic bone lesions after radiotherapy. Jap J Clin Oncol, 11 (suppl.) : 253-264, 1981. 
5) Schocker JD, Brady LW : Radiation therapy for bone metastasis. Clin Orthop Related Res, 169 : 38-43, 1982.

6) Springfield DS : Mechanism of metastasis. Clin Orthop Related Res, $169: 15-19,1982$.

7) Galasko CSB : Mechanism of bone destruction in the development of skeletal metastases. Nature, 263 : 507-518, 1976.

8) Cerino LE, King BJ : Growth of Vx-2 carcinoma in bone. Mayo Clin Proc, 38 : 484-489, 1963.
9) Galasko CSB : Skeletal Metastases. Butterworth \& Co Ltd, Cambridge, 1986, pl-51.

10) Dixon B, Bagnal DA : Metastasis and the excision of irradiated LMC1 tumors in the rat. Radiotherapy and Oncology, $47: 153-161$, 1985.

11) Yamasaki $\mathrm{H}$, Fukuda $\mathrm{K}$ et al. : Bone resorption by experimentally induced osteogenic tumor. J Bone and Miner Metab. 7 : 25-29. 1989. 
Rat model of bone metastasis obtained by mammary cancer transplantation

p 193 198

Akishige Ohta et al.

骨転移に対する放射線の照射効果を実験的に調べるため の動物モテルをつくることを目的として，近郊系のラット に発癌物質で発生させた乳癌細胞を骨䯣腔に移植し，形 態学的・X線学的検索を行い，骨転移ラットモテルの性 質について検討した。

[対象と方法] 乳癌(腺癌)は, 近郊系政性のFischer344系のラットに7,12-dimethylbenz (a) anthracene (DMBA) を释口投与して発生させた。この乳癌を同系のラット皮 下に移植して継代維持のできる移植性乳癌を得た。この 移植性乳癌細胞を同系ラットの骨䯣腔に注入して転移性 骨腫場の動物モデルを作成した。

本研究ては，乳癌細胞をラットの㮏の部位から大腿骨 の骨面膑に移植した時の動物の生存率の測定, X線写真 および組織病理学的検索を行った，また，乳癌細胞を移 植した大腿骨に对するX線照射の影瑤も調べた。

[結 果] 本実験て使用したラット移植性乳癌細胞 は，同系のラットの皮下あるいは骨㖪腔に移植すると， 移植したラットの全例に生着した。

100万個の乳湾細胞をラットの皮下および骨に移植し たときの生存日数は，それぞれ47士24日と21士11日であ った，乳癌細胞を移植された骨では，移植後約7日目頃 加線写真上に骨膜反応が認められた。

組織学的には移植後, 内膜および骨膜表面の休止期の 扁平な骨芽細胞層の近傍から多数の骨芽細胞と破骨細胞が 発生した．腫瑒組織の増大に伴って，既存骨およで新生骨 の両部位における破骨細胞による骨溶解と腫瘍細胞による 骨挰傷が進行して，最終的に骨析や骨破壊が起こって動物 は死に至る．乳癌細胞を骨に移植したラットでは，全例に 乳癌の肺への転移が起こった，一方，同様に皮下に移植し たラットで，乳癌の肺への転移は認められなかった，乳 癌細胞を移植した部位の骨をX線で照射するとラットの寿 命は延長した。

Radioimmunolocalization of human colorectal carcinoma xenografts with $F\left(a b^{\prime}\right)_{2}$ fragments of anti-sialyl Lewis a monoclonal antibody (MoAb) and a case report of radioimmunoscintigraphy with the radiolabelled fragment on recurrent rectal carcinoma patient

p 199 203

Junichi Sakamoto et al.

大腸癌培養細胞HT-29の細胞表面に発現しているシア ル化Lewis 抗原に対するモノクローナル抗体 (MoAB) H15を精製し，ペブシン，パパインにより $\mathrm{Fab}, \mathrm{F}\left(\mathrm{ab}^{\prime}\right)_{2}$ の fragment作成して, in vitro, in vivoの系において dosimetry analysisを行い, 腫場画像診断における有用性 を検討した。

[対象と方法] in vitroの系では，whole MoAbとFab， $\mathrm{F}\left(\mathrm{ab}^{\prime}\right)_{2}$ の抗原に対する親和性を大腸癌培養細胞株SW403 をターゲットとして, mixed hemmagglutination test (MHA)
にて判定した. in vivoの系では, whole MoAbと $\mathrm{F}\left(\mathrm{ab}^{\prime}\right)_{2}$ の 双方をクロラミンT法にで'2⿰氵より標識し、ヌードマウ ス腹腔内に投与し，その腫瘍 : 筋肉比, 腫場 : 肝比,お よび腫演：血液比を抗体投与直後より7日目まで連日測 定した。また，標識抗体投与後4日目には，移植大腸腫 偒，移植メラノーマ，血液，肝，正常大腸，および筋肉 における\% injected dose per gram (\%ID)の測定も行った.

ヌードマウスにおける腫瘍画像診断は， ${ }^{125}$ 標識抗体 (whole MoAbとF( $\left(\mathrm{ab}^{\prime}\right)_{2}$ fragment) 投与後連日シンチレーシ ヨンカメラを用いて，A-PおよびP-A画像の撮影を行っ た.

この結果をもとにして，直腸癌局所再発患者1例にお いて ${ }^{131}$ 標識 $F\left(a b^{\prime}\right)_{2}$ 抗体を投与し，ガンマカメラを用いて 抗体の局在を検討した．抗体投与による重篤な副作用は 認められなかった。

[結 果] ヨード標識をしたwhole MoAbと Fab, $\mathrm{F}\left(\mathrm{ab}{ }^{\prime}\right)_{2}$ の大腸癌細胞株SW403に対するMHAテストでは whole MoAbが $\times 10^{4}, \mathrm{Fab}$ が $\left.\times 10, \mathrm{~F}\left(\mathrm{ab}^{\prime}\right)_{2}\right)^{2} 5 \times 10^{3}$ の希釈 まで反応を示した.この結果，H-15MoAbに関しては, 放射性ヨード標識後はFab fragmentの抗原結合能がいち じるしく低下することが明らかになった。

in vivoの系においては，標識抗体投与後4７日目にお いて腫堭：筋肉比がwhole MoAbで×5, F $\left(\mathrm{ab}^{\prime}\right)_{2}$ では $\times 75$ であり, 腫瘍：肝比は, whole MoAbで×3，F(ab') 25, 腫瘍：血液比はwhole MoAbで ×1.5〜1.8であるのに 对し, $\mathrm{F}\left(\mathrm{ab}^{\prime}\right)_{2}$ で $\times 10$ と $\mathrm{F}\left(\mathrm{ab}^{\prime}\right)_{2}$ fragmentのより高い腫瘍 特異的集積が明らかになった。 また，\%IDも F(ab') は は移 植大腸腫笣 0.56 (whole MoAbでは0.36), 移植メラノーマ $0.03(0.08)$, 血液0.09 (0.25), 肝0.07 (0.10), 正常大腸 0.05 $(0.09)$, 筋肉0.02 (0.06) と移植大腸腫墽部において高値 を示していた。ヌードマウスにおける画像診断ては， $\left.\mathrm{F}(\mathrm{ab})_{2}\right)_{2}$ 抗体投与後36時間で, 移植大腸腫瘍部に抗体の集 皘がみられ, whole MoAbに比し，早期に腫瘍画像を得 ることができた。また，直腸癌局所再発症例において $\mathrm{F}\left(\mathrm{ab}^{\prime}\right)_{2}$ を投与した1例では，投与後3日目において腫瘍画 像が抽出され，臨床応用への有用性が示唆された。

[考察] wholeのMoAbに对 LF $\left(\mathrm{ab}^{\prime}\right)_{2}$ fragment 腫瘍 画像診断に用いることは，(1) 早いclearance，(2) 抗体の 腫湯へのaccess, (3) Fckよる非特異的集積の隇少などの 利点があるといわれている。

今回の検討により，in vivo，in vitro，また臨床の場に おいても $\mathrm{F}\left(\mathrm{ab}^{\prime}\right)_{2}$ fragmentの高度な腫笉特異的集積が証明 され，今後の臨床応用への有用性が示されたものと考之 られる。

Prognostic value of sialyl-Tn antigen in gastric carcinoma

p 205 208

Kiyoshi Maeda ot al.

近年，糖鎖抗原は腫瘍マーカーとして重要な位置を占 めている．糖鎖性腫煬マーカーの一つであるcarbohydrate antigen 19-9 (CA19-9), sialyl Lewis ${ }^{x}-\mathrm{i}$ (SLX) などは基幹桾 鎖を抗原としたものであるが，これに対しシアリル Tn 